DOI

\title{
ВИКЛАДАННЯ ПРАКТИЧНОЇ ПСИХОЛОГІЇ ТА ПЕДАГОГІКИ ВИЩОЇ ШКОЛИ МАГІСТРАНТАМ ЗІ СПЕЦІАЛЬНОСТІ “ТЕХНОЛОГІЇ ПАРФУМЕРНО-КОСМЕТИЧНИХ ЗАСОБІВ” У ЗАПОРІЗЬКОМУ ДЕРЖАВНОМУ МЕДИЧНОМУ УНІВЕРСИТЕТІ
}

Т. П. Зарічна

Запорізький державний медичний університет

\section{TEACHING OF APPLIED PSYCHOLOGY AND PEDAGOGICS FOR MASTERS ON SPECIALTY “TECHNOLOGY OF PERFUMERY AND COSMETICS” IN ZAPORIZHIAN STATE MEDICAL UNIVERSITY}

\author{
Zaporizhian State Medical University
}

\begin{abstract}
Вища освіта, яка є складовою системи освіти України, забезпечує наукову, професійну та практичну підготовку за рядом освітньо-кваліфікаційних рівнів, серед яких є “Магістр”.

Згідно з навчальним планом магістерської підготовки, передбачено вивчення магістрантами спеціальності “Технології парфумерно-косметичних засобів” дисципліни “Практична психологія та педагогіка вищої школи”.

Метою даної роботи стало узагальнення досвіду викладання даної дисципліни магістрантам зазначеної спеціальності у Запорізькому державному медичному університеті, в тому числі подання комплексу методичного забезпечення дисципліни, який спрямований на оптимізацію теоретичних знань та практичних навичок, придбання магістрантами необхідних компетенцій для якісного виконання своїх професійних обов’язків.
\end{abstract}

Higher education is a part of Ukrainian education system, it provides scientific, professional and practical training in a range of educational levels, among which is the "master".

According to curriculum Master training are undergraduates studying specialty "Technology of perfumery and cosmetics" of discipline "Practical Psychology and Pedagogics".

The aim of this study was to summarize the experience of teaching the discipline under graduates this specialty in the Zaporizhian State Medical University, including the presentation of complex methodical main tenance of discipline that was directed on optimizing that theoretical knowledge and practicals kills, acquisition required competencies for efficient performance of their professional duties for masters.

Вступ. Вища освіта є складовою системи освіти України і грунтується на Законі України “Про вищу освіту” та інших нормативних документах [1-3]. Вона забезпечує фундаментальну наукову, професійну та практичну підготовку за такими освітньокваліфікаційними рівнями, як: “Молодший спеціаліст”, “Бакалавр”, “Спеціаліст”, “Магістр”. За цією схемою проводиться підготовка медичних і фармацевтичних кадрів.

У структурі вищої освіти України ступінь магістра йде за ступенем бакалавра і спеціаліста і передує ступеню кандидата наук. Ступінь магістра $є$ академічним, оскільки він відображає передусім освітянський рівень випускника вищої школи і свідчить про наявність у нього умінь і навичок, які притаманні починаючому науковцю $[4,5]$.

(c) Т. П. Зарічна
Навчальний план магістерської підготовки складається з таких трьох циклів дисциплін, як:

- цикл професійно-орієнтованої гуманітарної і соціально-економічної підготовки;

- цикл наукової, професійної та практичної підготовки;

- цикл вибіркових дисциплін.

Серед зазначених дисциплін передбачено вивчення магістрантами "Практичної психології та педагогіки вищої школи”.

Основна частина. Метою даної роботи стало узагальнення досвіду викладання “Практичної психології та педагогіки вищої школи” магістрантам спеціальності “Технології парфумернокосметичних засобів” у Запорізькому державному медичному університеті.

Згідно з робочою програмою, яку складено на підставі навчальної програми дисципліни та на- 
вчального плану університету, метою викладання зазначеної дисципліни є сприяння формуванню у магістрантів відповідних психологічних якостей, оволодіння ними основ педагогіки вищої школи.

Основними завданнями вивчення дисципліни “Практична психологія та педагогіка вищої школи” $€$ формування у магістрантів знань з питань:

- управління конфліктами та стресами;

- ділового етикету;

- біоетики;

- методів психологічного впливу в системах керування;

- загальних основ педагогіки вищої школи.

Згідно з вимогами освітньо-професійної програми та освітньо-кваліфікаційної характеристики, магістранти повинні вміти [6, 7]:

- виходити з конфліктних ситуацій;

- застосовувати основні принципи фармацевтичної етики та деонтології;

- обирати і застосовувати в різних ситуаціях методи психологічного впливу;

- застосовувати правила ділового етикету;

- вибирати, обгрунтовувати та застосовувати форми, методи і засоби навчання у вищій школі;

- вибирати і раціонально впроваджувати ефективні методи, форми виховання, посилювати мотивацію у навчанні, вихованні та самовихованні;

- обирати та застосовувати методи ефективної організаційно-управлінської педагогічної діяльності та методи навчання, здійснювати контроль результатів навчання у вищому навчальному закладі.

Загальна трудомісткість дисципліни складає 108 годин, із яких на лекції відводиться 12 годин, практичні заняття - 42 години, самостійну роботу 54 години.

В структурному плані дисципліна поділена на дві частини:

- практична психологія;

- педагогіка вищої школи.

Для проведення навчального процесу і ефективного засвоєння матеріалу розроблено навчальнометодичний комплекс, який включає конспект лекцій у вигляді презентації, навчально-методичні посібники для виконання практичної роботи (дві частини) і самостійної роботи магістрантами, збірник тестів і ситуаційних задач за конкретними темами. Впровадження тестової системи оці- нювання знань дозволяє здійснювати їх поточний контроль.

Під час лекції особлива увага приділяється вивченню основ конфліктології, ділового етикету у фармацевтичній діяльності, психологічних аспектів діяльності керівника, основних категорій педагогіки вищої школи, особливостей праці викладача вищого навчального закладу, його педагогічної культури, студентства як об’єкта - суб’єкта педагогічної діяльності.

На практичних заняттях та самостійно магістранти поглиблюють знання, отримані на лекціях, а також вивчають причини та методи профілактики стресів, біоетичні аспекти у фармації, психологопедагогічні аспекти ділового спілкування, етику викладача, теорії виховання, форми та методи виховання, психологію особистості, мотиваційну основу пізнавальної діяльності, психологічну структуру діяльності, форми та методи організації навчальної роботи у вищому навчальному закладі, принципи, методи та засоби навчання, види і форми контролю, критерії оцінки знань, умінь та ін.

Розроблений навчально-методичний комплекс спрямований на оптимізацію теоретичних знань та практичних навичок, які потрібні для придбання необхідних компетенцій та якісного виконання своїх професійних обов’язків [8, 9].

У процесі вивчення дисципліни контроль знань магістрантів здійснюється в наступних формах:

- поточний контроль - за темами дисципліни (опитування магістрантів, розв'язування тестів, бліц-опитування);

- проміжний контроль - по закінченню вивчення розділів (тестування, захист контрольних творчих завдань);

- підсумковий контроль - по закінченню вивчення курсу (комп’ютерний іспит, залік практичних навичок, співбесіда).

Висновки. Узагальнено досвід викладання “Практичної психології та педагогіки вищої школи” магістрантам зі спеціальністю “Технології парфумерно-косметичних засобів” у Запорізькому державному медичному університеті.

Реалізація розробленого навчально-методичного комплексу зазначеної дисципліни дозволить здійснити якісну підготовку магістрантів даної спеціальності для їх подальшої успішної професійної діяльності. 


\section{Список літератури}

1. Про вищу освіту [Електронний ресурс] : Закон України від 01.07.2014 р. № 1556-VII.- Режим доступу : http://zakon1.rada.gov.ua/laws/show/1556-18.

2. Про затвердження національної рамки кваліфікацій [Електронний ресурс] : Постанова Кабінету Міністрів України від 23 листопада 2011 р. № 1341. - Режим доступу : http://zakon2.rada.gov.ua/laws/show/1341-2011$\% \mathrm{D} 0 \% \mathrm{BF}$

3. Про затвердження Положення про особливості ступеневої освіти медичного спрямування [Електронний ресурс] : наказ МОЗ України від 24.02.2000 р. № 35. - Режим доступу : http://zakon4.rada.gov.ua/laws/ show/z0370-00.

4. Про внесення змін і доповнень до Тимчасових правил прийому до магістратури в медичних вищих навчальних закладах [Електронний ресурс] : наказ МОЗ України від 24.09.1996 р. № 295. - Режим доступу : http:// zakon4.rada.gov.ua/laws/show/z0697-96.

5. Про затвердження Положення про спеціалізацію (інтернатуру) випускників вищих медичних і фармацевтичних закладів освіти III-IV рівнів акредитації [Електронний ресурс] : наказ МОЗ України від 19.09.1996 р. № 291. - Режим доступу : http://zakon4. rada.gov.ua/laws/show/z0696-96.
6. Освітньо-кваліфікаційна характеристика магістра за спеціальністю 8.110202 “Технологія парфумернокосметичних засобів” напряму підготовки 1102 “Фармація” : наказ МОН України від 16.09.2006 р. № 196 “Про затвердження складових галузевих стандартів вищої освіти зі спеціальностей 8.110204 “Технологія фармацевтичних препаратів”, 8.110206 “Клінічна фармація” напряму підготовки 1102 “Фармація”. - К., 2014.

7. Освітньо-професійна програма підготовки магістра за спеціальністю 8.110202 “Технологія парфумернокосметичних засобів” напряму підготовки 1102 “Фармація” : наказ МОН України від 16.09.2006 р. № 196 “Про затвердження складових галузевих стандартів вищої освіти зі спеціальностей 8.110204 “Технологія фармацевтичних препаратів”, 8.110206 “Клінічна фармація” напряму підготовки 1102 “Фармація”. - К., 2014.

8. Довідник кваліфікаційних характеристик професій працівників системи охорони здоров’я. Вип. 78: Охорона здоров'я / Міністерство охорони здоров’я України, Міністерство праці та соціальної політики України. К., 2002. - 372 с.

9. Національний класифікатор України: “Класифікатор професій” ДК 003:2010. - К. : Видавництво “Соцінформ”, 2010. 